\title{
Identification and Characterization of a Novel Salt-Tolerant Esterase from the Deep-Sea Sediment of the South China Sea
}

\author{
Yi Zhang1, Jie Hao', Yan-Qi Zhang1, Xiu-Lan Chen', Bin-Bin Xie', Mei Shi', \\ Bai-Cheng Zhou ${ }^{1}$, Yu-Zhong Zhang ${ }^{1,2}$ and Ping-Yi Li ${ }^{1 *}$
}

'State Key Laboratory of Microbial Technology, Marine Biotechnology Research Center, Institute of Marine Science and Technology, Shandong University, Jinan, China, ${ }^{2}$ Laboratory for Marine Biology and Biotechnology, Qingdao National Laboratory for Marine Science and Technology, Qingdao, China

Marine esterases play an important role in marine organic carbon degradation and cycling. Halotolerant esterases from the sea may have good potentials in industrial processes requiring high salts. Although a large number of marine esterases have been characterized, reports on halotolerant esterases are only a few. Here, a fosmid library containing 7,200 clones was constructed from a deep-sea sediment sample from the South China Sea. A gene $\mathrm{H} 8$ encoding an esterase was identified from this library by functional screening and expressed in Escherichia coli. Phylogenetic analysis showed that $\mathrm{H} 8$ is a new member of family $\mathrm{V}$ of bacterial lipolytic enzymes. H8 could effectively hydrolyze short-chain monoesters (C4-C10), with the highest activity toward $p$-nitrophenyl hexanoate. The optimal temperature and $\mathrm{pH}$ for $\mathrm{H} 8$ activity were $35^{\circ} \mathrm{C}$ and $\mathrm{pH} 10.0$, respectively. $\mathrm{H} 8$ had high salt tolerance, remaining stable in $4.5 \mathrm{M} \mathrm{NaCl}$, which suggests that $\mathrm{H} 8$ is well adapted to the marine saline environment and that $\mathrm{H} 8$ may have industrial potentials. Unlike reported halophilic/halotolerant enzymes with high acidic/basic residue ratios and low pl values, $\mathrm{H} 8$ contains a large number of basic residues, leading to its high basic/acidic residue ratio and high predicted pl (9.09). Moreover, more than 10 homologous sequences with similar basic/acidic residue ratios and predicted pl values were found in database, suggesting that $\mathrm{H} 8$ and its homologs represent a new group of halotolerant esterases. We also investigated the role of basic residues in $\mathrm{H} 8$ halotolerance by site-directed mutation. Mutation of Arg195, Arg203 or Arg236 to acidic Glu significantly decreased the activity and/or stability of $\mathrm{H} 8$ under high salts, suggesting that these basic residues play a role in the salt tolerance of $\mathrm{H} 8$. These results shed light on marine bacterial esterases and halotolerant enzymes.

Keywords: esterase, salt-tolerance, deep-sea sediment, metagenomics, basic residues

\section{INTRODUCTION}

Lipolytic enzymes, including esterases and lipases, are involved in catalyzing the hydrolysis and synthesis of esters. Esterases usually hydrolyze water-soluble short-chain monoesters, while lipases prefer water-insoluble long-chain triglycerides (Jaeger et al., 1999). Marine lipolytic enzymes play an important role in marine organic carbon degradation and cycling. A large number of active 
microbial lipolytic enzymes have been discovered from surface and deep-sea seawater (Chu et al., 2008; Fang et al., 2014), hydrothermal vents (Placido et al., 2015), and marine sediments (Li et al., 2014), suggesting their potential roles in marine ecosystems.

Marine environments usually contain $\sim 3.5 \%$ (w/v) $\mathrm{NaCl}$, and in some salterns, the salinity can even reach as high as 37\% (w/v) (Ventosa et al., 2014). Many microbial enzymes of marine origin have evolved to be halotolerant or halophilic. Several halotolerant or halophilic lipolytic enzymes have been discovered from marine environments, including a halotolerant esterase (Est10) from Psychrobacter pacificensis (Wu et al., 2013), a halophilic esterase (LipC) from Haloarcula marismortui (Rao et al., 2009), a halotolerant esterase (ThaEst2349) from Thalassospira sp. (De Santi et al., 2016), and a halophilic lipase (LipBL) from Marinobacter lipolyticus (Perez et al., 2011). Studies on halotolerant/halophilic lipolytic enzymes and other halophilic enzymes show that these proteins have a significant increase in negatively charged acidic amino acid residues over their surfaces, which may form protective hydrated ion network and promote the adaption of the protein to salinity (Oren et al., 2005). The increase in acidity over the surface also prevents the aggregation of proteins (Elcock and Mccammon, 1998). However, there is also a report showing that an increase in positively charged basic residues on the enzyme surface may contribute to the adaption of an endonuclease $V$ sEndA from Vibrio salmonicida to saline habitat (Altermark et al., 2008). Thus, halotolerant and halophilic enzymes may have diverse salt-adapted strategies. The halotolerance of lipolytic enzymes can help themselves and the strains producing them well adapt to the saline environments and play a role in marine organic carbon degradation and cycling. It has been reported that halotolerant/halophilic lipolytic enzymes have potentials in industrial processes requiring high salts, low water activity, and the presence of organic solvents.

Based on amino acid sequences and biochemical properties, microbial lipolytic enzymes have been classified into eight families (families I-VIII) (Arpigny and Jaeger, 1999). Enzymes grouped in family $\mathrm{V}$ originates from a wide variety of bacteria, including mesophilic, psychrophilic, and thermophilic organisms (Arpigny and Jaeger, 1999). Recently, many members of family $\mathrm{V}$ lipolytic enzymes have been discovered (Prive et al., 2013; Sumby et al., 2013; Tchigvintsev et al., 2015). This family contains lipases and esterases, displaying diverse substrate specificities and characteristics (Peng et al., 2011; Chen et al., 2013; Pereira et al., 2015). However, studies on the salt tolerance of this family are still scarce.

Marine environments benefit the discovery of novel enzymes with special characteristics. Because more than 99\% of marine microorganisms are still uncultured (Schloss and Handelsman, 2003), metagenomics, a cultivation-independent method, has been developed to discover new functional genes from both cultured and uncultured microorganisms (Handelsman, 2004). The application of functional metagenomics has led to the discovery of several new lipases and esterases from diverse marine environments, such as intertidal flat (Kim et al., 2009), tidal flat sediment (Jeon et al., 2012), and marine surface water (Chu et al., 2008).

To identify novel esterases from marine sediments, in this study, a fosmid library of a deep-sea sediment sample from the South China Sea was constructed, and functional metagenomic screening was performed to obtain novel esterases. A lipolytic enzyme gene $H 8$ was identified from the library, and the encoding esterase $\mathrm{H} 8$ was expressed and characterized. The result showed that $\mathrm{H} 8$ was a new member of family $\mathrm{V}$ of bacterial lipolytic enzymes with a substrate preference toward short-chain monoesters (C4-C10). H8 displayed high halotolerance. The sequence of $\mathrm{H} 8$ contains a large number of basic residues, leading to a high basic/acidic residue ratio and a high predicted isoelectric point (pI). The roles of basic residues in $\mathrm{H} 8$ halotolerance were investigated by site-directed mutagenesis. Sequence analysis suggests that $\mathrm{H} 8$ together with its homologs represent a new group of halotolerant esterases. These results shed light on marine bacterial esterases and halotolerant enzymes.

\section{MATERIALS AND METHODS}

\section{Sample Collection and DNA Extraction}

Marine sediment sample S100 was collected from the South China Sea $\left(13.5^{\circ} \mathrm{N}, 118^{\circ} \mathrm{E}\right)$ at a water depth of $3,939 \mathrm{~m}$ in September 2011. Temperature and salinity of bottom water in this area was $2.4^{\circ} \mathrm{C}$ and $3.46 \%(\mathrm{w} / \mathrm{v})$, respectively. The sample was stored at $-20^{\circ} \mathrm{C}$ until processing. Environmental genomic DNA was extracted from the sample by following the SDS-based extraction procedure described by Zhou et al. (1996).

\section{Metagenomic Library Construction and Screening of Lipolytic Enzymes}

The DNA extract was separated by pulsed-filed gel electrophoresis (PFGE), and DNA bands of $\sim 35 \mathrm{kbp}$ in the gel were extracted by gelase enzymolysis and ethanol precipitation. A metagenomic DNA library was constructed using the CopyControl Fosmid Library Production Kit (Epicentre Biotechnologies, Madison, WI, USA) by following the manufacturer's instructions. A total of 7,200 fosmid clones were obtained, which were spread onto Luria-Bertani (LB) agar plates supplemented with $1 \%(\mathrm{v} / \mathrm{v})$ emulsified tributyrin to screen clones with lipolytic enzyme activity. Clones exhibiting a clear zone around the colony were selected to construct their respective subcloning libraries. Fosmid DNA was extracted from positive clones and partially digested by the restriction enzyme Sau3AI. The DNA fragments of 1.5-5 kbp were recovered from an agarose gel, end-repaired and ligated into the pUC19 vector that had been digested by BamHI and pretreated by bacterial alkaline phosphatase. The ligated products were transformed into E. coli TOP10 cells, and the transformants were spread onto LB agar plates supplemented with $100 \mu \mathrm{g} / \mathrm{ml}$ ampicillin and $1 \%(\mathrm{v} / \mathrm{v})$ tributyrin. Transformants forming clear zones were sequenced. The open reading frames (ORFs) in the sequenced 
DNA fragments were predicted by the GeneMark program ${ }^{1}$ and the genes encoding potential lipolytic enzymes were identified by using the blastx program against the NCBI nonredundant protein database (nr). Multiple sequence alignment was performed using MUSCLE (Edgar, 2004). Phylogenetic analysis was carried out with the neighbor-joining method using MEGA 6.0 (Tamura et al., 2013). The potential signal peptide sequence was predicted by SignalP 4.0 (Petersen et al., 2011).

\section{Gene Cloning and Protein Expression and Purification}

The gene $H 8$ encoding a lipolytic enzyme was amplified from the fosmid DNA using the primer pair of H8_F ( $5^{\prime}$-GGGAATTC CATATGCAGTCTGGCACGGTGAG-3', NdeI digestion site was underlined) and H8_R (5'-CCGCTCGAGCGCCACCGCCGGT TGCGCC-3', XhoI digestion site was underlined), and cloned into the expression vector pET-22b.

The constructed plasmid pET-22b-H8 was transformed into E. coli BL21 (DE3). Transformants were cultured at $37^{\circ} \mathrm{C}$ and $180 \mathrm{rpm}$ in LB liquid medium containing $100 \mu \mathrm{g} / \mathrm{mL}$ ampicillin. When the $\mathrm{OD}_{600}$ of cells reached approximately $0.6,1 \mathrm{mM}$ isopropyl- $\beta$-D-thiogalactopyranoside (IPTG) was added for the induction of protein expression. Then, the culture was incubated at $20^{\circ} \mathrm{C}$ and $110 \mathrm{rpm}$ for $20 \mathrm{~h}$. After incubation, the cells in the culture were harvested, resuspended in lysis buffer $(50 \mathrm{mM}$ Tris- $\mathrm{HCl}, 100 \mathrm{mM} \mathrm{NaCl}, \mathrm{pH}$ 8.0) and disrupted by pressure. The recombinant His-tagged protein in the extract was first purified by Ni affinity chromatography (Qiagen, USA), and further purified by gel filtration chromatography on a Superdex 200 column (GE healthcare, Sweden). Protein concentrations were determined by using the Pierce BCA Protein Assay Kit (Thermo Scientific, USA).

\section{Enzyme Assays}

The esterase activity was measured by monitoring the hydrolysis of $p$-nitrophenyl ( $p N P$ ) esters (Sigma, USA) using a spectrophotometric method (Shirai and Jackson, 1982). The reaction mixture contained $50 \mathrm{mM}$ Tris- $\mathrm{HCl}$ buffer $(\mathrm{pH} 8.0)$, $0.02 \mathrm{ml}$ of $10 \mathrm{mM}$ substrate, and $0.02 \mathrm{ml}$ enzyme with appropriate concentration in a final volume of $1 \mathrm{~m} 1$. After incubation at an indicated temperature for $5 \mathrm{~min}$, the reaction was terminated by an addition of $0.1 \mathrm{ml} 20 \%(\mathrm{w} / \mathrm{v})$ SDS. The absorbance of the reaction mixture at $405 \mathrm{~nm}$ was measured to detect the amount of released p-nitrophenol (Li et al., 2014). The background hydrolysis of the substrate was determined by using a blank control with a composition identical with the reaction mixture except that the enzyme was replaced by buffer. One unit of enzyme $(U)$ is defined as the amount of enzyme required to liberate $1 \mu \mathrm{mol} p$-nitrophenol per minute.

\section{Biochemical Characterization of $\mathrm{H8}$}

The substrate specificity of $\mathrm{H} 8$ was investigated using the substrates $p \mathrm{NP}$ acetate $(\mathrm{C} 2), p \mathrm{NP}$ butyrate $(\mathrm{C} 4), p \mathrm{NP}$ caproate

${ }^{1}$ http://topaz.gatech.edu/GeneMark/
(C6), $p \mathrm{NP}$ caprylate (C8), $p \mathrm{NP}$ decanoate (C10), $p \mathrm{NP}$ laurate (C12), $p$ NP myristate (C14), and $p$ NP palmitate (C16) (Sigma, USA). The optimum temperature for $\mathrm{H} 8$ activity was measured at temperatures ranging from 0 to $60^{\circ} \mathrm{C}$ at $\mathrm{pH} 8.0$. For thermostability assay, the enzyme was incubated at temperatures ranging from 0 to $60^{\circ} \mathrm{C}$ for $1 \mathrm{~h}$, and then the residual activity was measured at $35^{\circ} \mathrm{C}$. The optimum $\mathrm{pH}$ of $\mathrm{H} 8$ was determined at $35^{\circ} \mathrm{C}$ in the Britton-Robinson buffers ranging from $\mathrm{pH} 4.0$ to 13.0. For $\mathrm{pH}$ stability assay, the enzyme was incubated in buffers with a $\mathrm{pH}$ range of $4.0-13.0$ at $25^{\circ} \mathrm{C}$ for $1 \mathrm{~h}$, and then the residual activity was measured at $\mathrm{pH} 8.0$ and $35^{\circ} \mathrm{C}$. The effect of $\mathrm{NaCl}$ on $\mathrm{H} 8$ activity was determined at $\mathrm{NaCl}$ concentrations ranging from 0 to $4.8 \mathrm{M}$. For salt tolerance assay, the enzyme was incubated at $0^{\circ} \mathrm{C}$ for $1 \mathrm{~h}$ in buffers containing $\mathrm{NaCl}$ ranging from 0 to $4.6 \mathrm{M}$ before the residual activity was measured at $35^{\circ} \mathrm{C}$.

The effects of metal ions $\left(\mathrm{K}^{+}, \mathrm{Li}^{+}, \mathrm{Ba}^{2+}, \mathrm{Ca}^{2+}, \mathrm{Co}^{2+}, \mathrm{Cu}^{2+}\right.$, $\mathrm{Fe}^{2+}, \mathrm{Mg}^{2+}, \mathrm{Mn}^{2+}, \mathrm{Ni}^{2+}$, and $\mathrm{Zn}^{2+}$ ) and potential inhibitors ( $\beta$-mercaptoethanol, DTT, Thiourea, Urea, EDTA, and PMSF) on $\mathrm{H} 8$ activity were examined at $\mathrm{pH} 8.0$ and $35^{\circ} \mathrm{C}$ in a final concentration of $1 \mathrm{mM}$ or $10 \mathrm{mM}$. The effects of organic solvents on $\mathrm{H} 8$ activity were examined using methanol, ethanol, isopropanol, acetone, acetonitrile, dimethylsulfoxide (DMSO), and dimethylformamide (DMF) at final concentrations of $10 \%$ and $20 \%(\mathrm{v} / \mathrm{v})$. The effects of Tween 20, Tween 80, and Triton $\mathrm{X}-100$ on $\mathrm{H} 8$ activity were examined at final concentrations of $0.001-0.1 \%(\mathrm{v} / \mathrm{v})$. The effect of SDS on enzyme activity was measured at final concentrations of $0.001-0.1 \%(\mathrm{w} / \mathrm{v})$.

\section{Site-Directed Mutagenesis of H8}

Using plasmid pET-22b-H8 as the template, site-directed mutagenesis on $H 8$ was performed with the QuikChange ${ }^{\circledR} 146$ mutagenesis kit II (Agilent technologies, USA) according to the method of QuikChange site-directed mutagenesis (Liu and Naismith, 2008). After verified by DNA sequencing, mutated plasmids were transformed into E. coli BL21 (DE3) for protein expression. The purification of $\mathrm{H} 8$ mutants was performed under the same conditions as those of the wild type (WT) H8.

\section{Enzyme Kinetic Assays}

Enzyme kinetic assays of $\mathrm{H} 8$ and its mutants were carried out at pH 7.5 (50 mM Tris- $\mathrm{HCl}$ ) using pNPC6 at concentrations from 0.02 to $2.0 \mathrm{mM}$. Kinetic parameters were calculated by non-linear regression fit directly to the Michaelis-Menten equation using the Origin8.5 software.

\section{Circular Dichroism Spectroscopy}

Circular dichroism (CD) spectra of WT H8 and its mutants were recorded at $25^{\circ} \mathrm{C}$ on a J-810 spectropolarimeter (JASCO, Japan). All the spectra were collected from 200 to $250 \mathrm{~nm}$ at a scanning speed of $200 \mathrm{~nm} / \mathrm{min}$ with a path length of $0.1 \mathrm{~cm}$. Proteins for CD spectroscopy assays were at a concentration of $0.3 \mathrm{mg} / \mathrm{ml}$ in $50 \mathrm{mM}$ Tris- $\mathrm{HCl}$ buffer ( $\mathrm{pH} 8.0$ ).

\section{Nucleotide Sequence Accession Number}

The nucleotide sequence of $\mathrm{H} 8$ has been deposited in the GenBank database under accession number KY273927. 

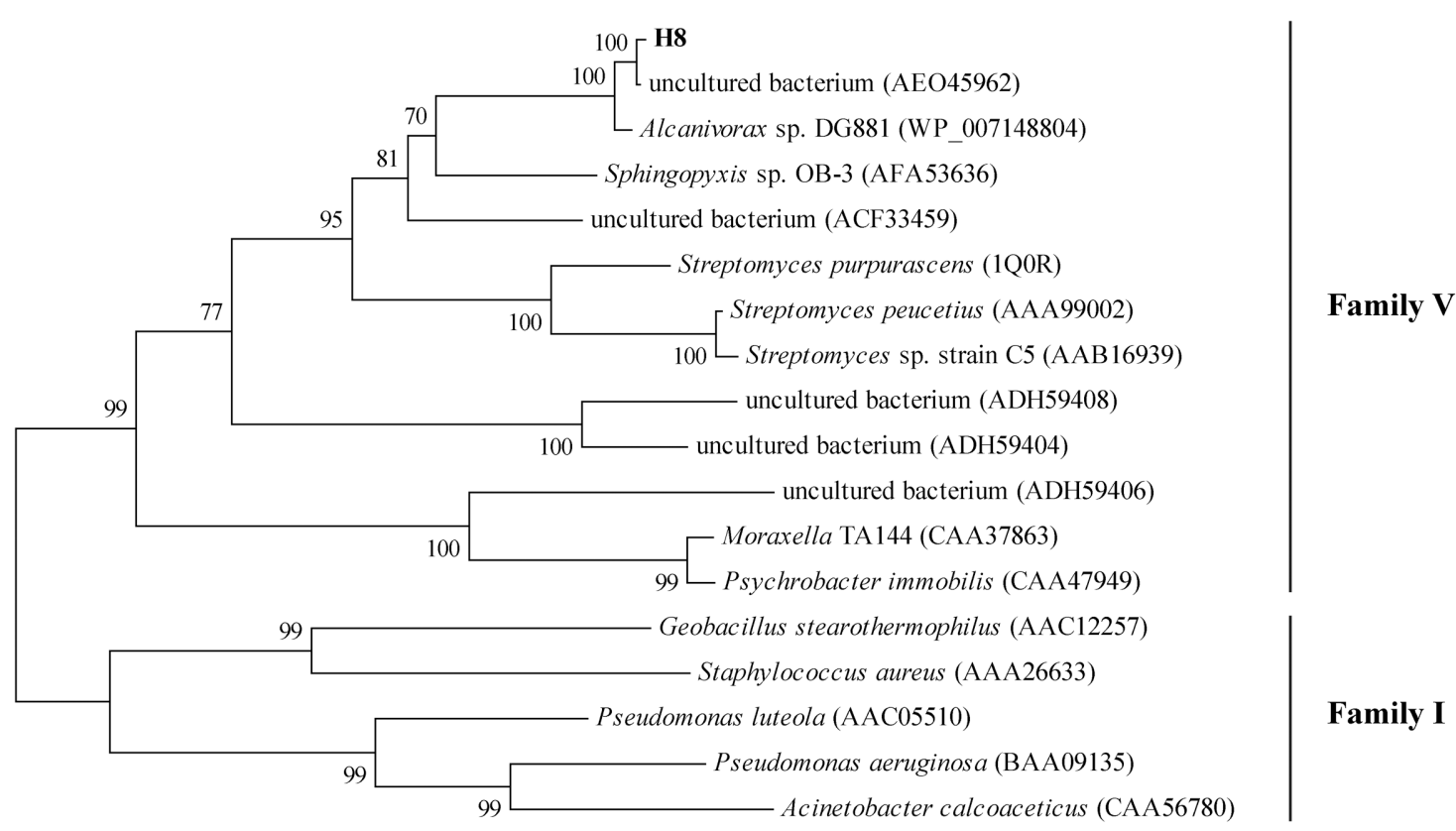

0.5

FIGURE 1 | Phylogenetic tree of esterase H8 and representative lipolytic enzyme sequences from family V. The tree was built by Neighbor-Joining method with JTT-matrix based model using 218 amino acid positions. Bootstrap analysis of 1000 replicates was executed and values above $50 \%$ are shown. The scale for branch length is shown below the tree. Lipases from family I were used as outgroups.

\section{WP 035248324 WP 011589723 WP 035232050 WP_008927335 WP_055099840 WP_022993941 AJD 46901 \\ WP_013805214 KIQ18344 WP_004579301 He}

\section{WP_035248324 WP_011589723 WP_035232050 WP 008927335 WP-022993941 $\mathrm{AJD} 46901$ WP 013805214 KI- 18344 WP_004579301}

\section{WP 035248324} WP 011589723 WP 035232050 WP_008927335 WP_055099840 WP_022993941 $\mathrm{AJ} \overline{\mathrm{D}} 46901$ WP 013805214 KIQ̄18344 WP_00457930 H8
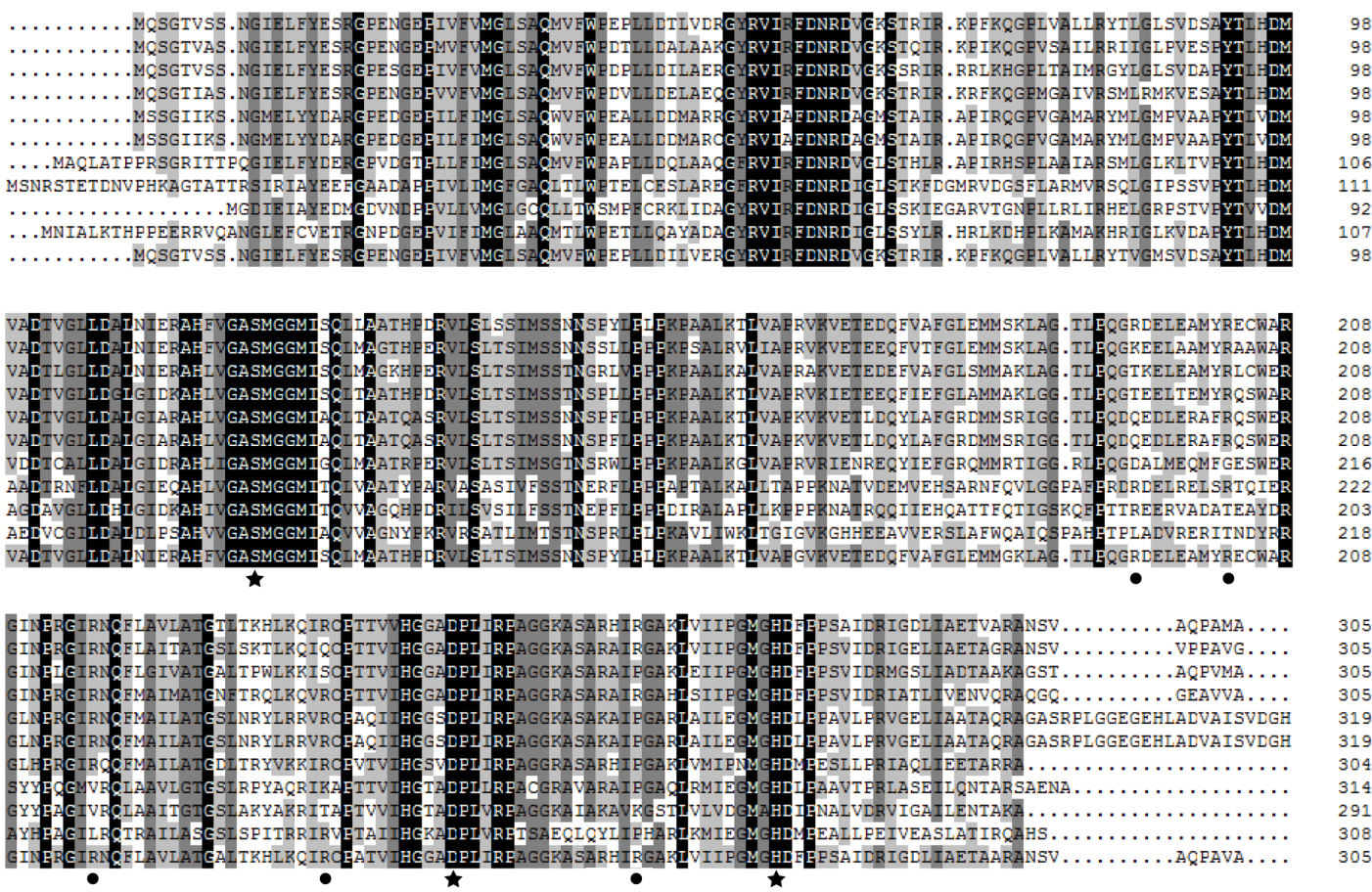

FIGURE 2 | Multiple sequence alignment of $\mathbf{H 8}$ and its homologs. Identical and similar amino acids are shaded in black and gray, respectively. Stars indicate amino acid residues belonging to the catalytic triad, and circles indicate basic amino acid residues (Arg195, Arg203, Arg216, Arg236, and Arg263) selected for site-directed mutation. Sequence analysis suggested that residues Arg203, Arg216, and Arg236 are highly conserved, and residues Arg195 and Arg263 are partially conserved. 

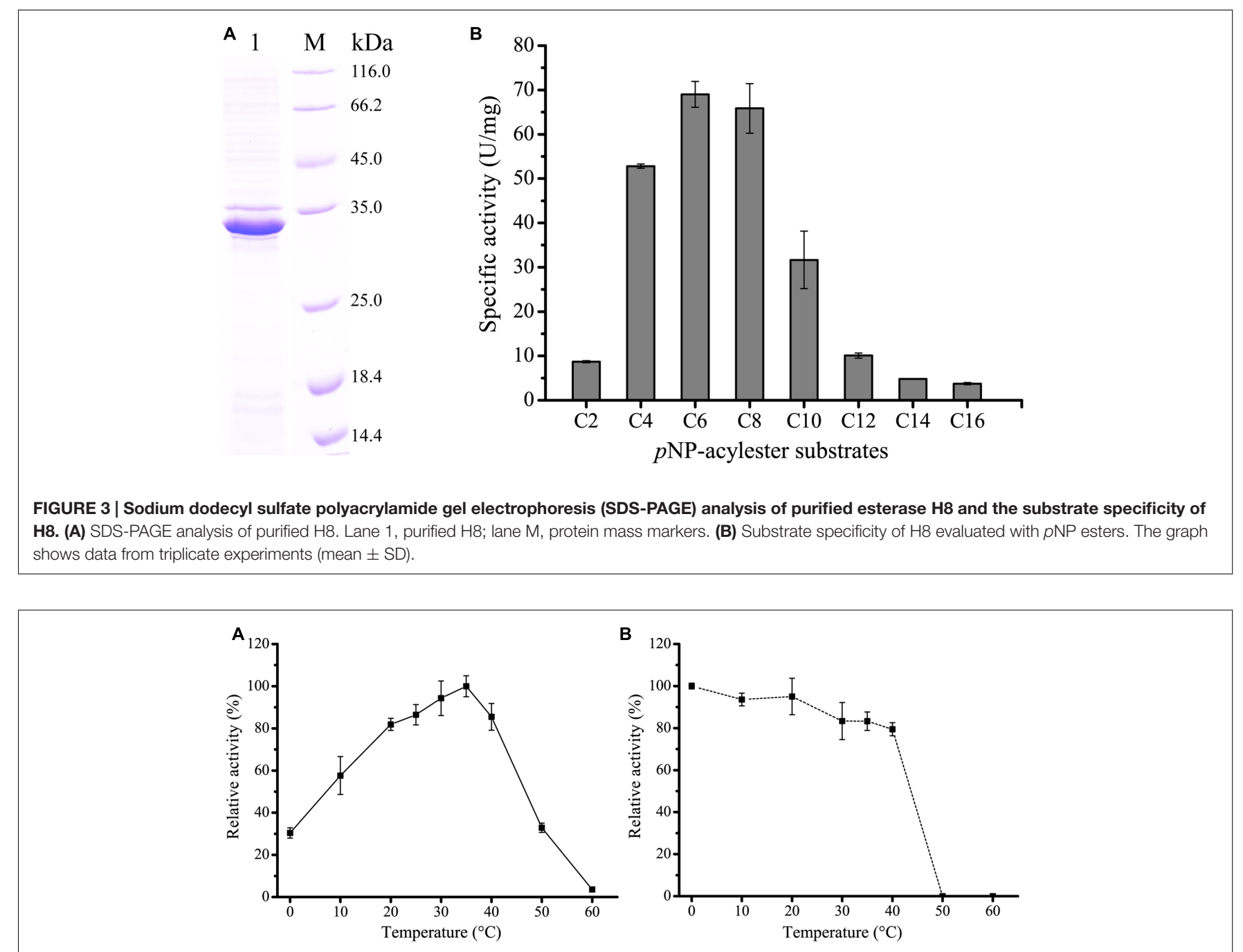

FIGURE 4 | Effect of temperature on the activity and stability of H8. (A) Effect of temperature on $\mathrm{H} 8$ activity. The highest activity of $\mathrm{H} 8$ at $35^{\circ} \mathrm{C}(69.2 \mathrm{U} / \mathrm{mg})$ was taken as $100 \%$. (B) Effect of temperature on the stability of $\mathrm{H} 8$. The enzyme was incubated at $0-60^{\circ} \mathrm{C}$ for $1 \mathrm{~h}$. The remaining activity was measured under optimal conditions. The activity at $0^{\circ} \mathrm{C}(66.4 \mathrm{U} / \mathrm{mg})$ was taken as $100 \%$. The graphs show data from triplicate experiments (mean \pm SD).
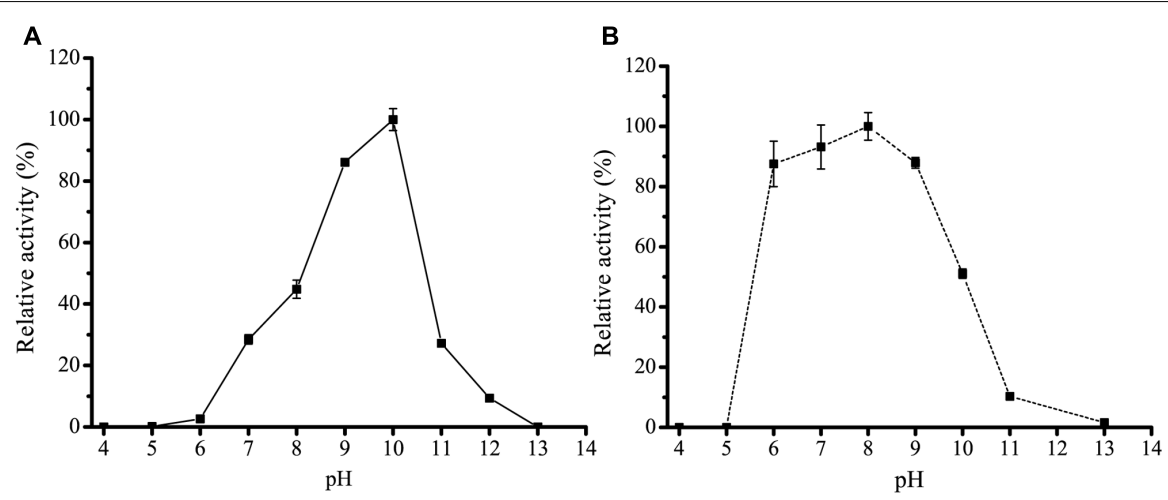

FIGURE 5 | Effect of $\mathbf{p H}$ on the activity and stability of $\mathbf{H 8}$. (A) Effect of $\mathrm{pH}$ on the activity of $\mathrm{H} 8$. The activity was measured at $35^{\circ} \mathrm{C}$ in Britton-Robinson buffers ranging from $\mathrm{pH} 4.0$ to 13.0. The highest activity at pH $10.0(70.2 \mathrm{U} / \mathrm{mg})$ was taken as $100 \%$. (B) Effect of pH on the stability of H8. The enzyme was incubated in buffers ranging from $\mathrm{pH} 4.0$ to 13.0 at $25^{\circ} \mathrm{C}$ for $1 \mathrm{~h}$. The remaining activity was measured under optimal conditions. The highest activity at pH $8.0(54.4 \mathrm{U} / \mathrm{mg})$ was taken as $100 \%$. The graphs show data from triplicate experiments (mean \pm SD). 


\section{RESULTS}

\section{Functional Metagenomic Screening of Lipolytic Enzymes}

A metagenomic library was constructed from a deep-sea sediment sample from the South China Sea, which contained a total of 7,200 fosmid clones. The metagenomic library represented approximately $252 \mathrm{Mbp}$ environmental DNA assuming an average insert size of $35 \mathrm{kbp}$. By functional assays, 10 fosmid clones showing lipolytic enzyme activities were screened from this library. The sequences of putative lipolytic enzymeencoding genes in the identified fosmids were determined by subcloning library construction and subsequent sequencing. Among these genes, the gene $H 8$ containing 918 bp was predicted to encode a lipolytic enzyme and chosen for further analysis.

\section{Sequence Analysis of the Lipolytic Enzyme H8}

The gene $H 8$ encodes a lipolytic enzyme of 305 amino acid residues with a predicted molecular weight of $32.8 \mathrm{kDa}$ and a predicted $\mathrm{pI}$ of 9.09. Prediction by SignalP 4.0 suggested that $\mathrm{H} 8$ may lack an $\mathrm{N}$-terminal signal sequence. Among the characterized lipolytic enzymes, $\mathrm{H} 8$ showed the highest sequence identity $(46 \%)$ to a family $\mathrm{V}$ esterase (Est16) from a microbial consortium specialized for diesel oil degradation (Pereira et al., 2015). Phylogenetic tree also showed that H8 belongs to the family V of bacterial lipolytic enzymes (Figure 1). Based on sequence alignments with other proteins from family $\mathrm{V}$, the catalytic triad of H8 was identified, which is composed of Ser120, Asp247, and His275 (Figure 2). The catalytic Ser120 is located in the conserved GASMGGMI motif, Asp247 in the conserved DPL motif, and His275 in the conserved MG/AHD motif.

\section{Expression and Characterization of the Esterase $\mathrm{H8}$}

H8 was over-expressed in E. coli BL21 (DE3), and the recombinant $\mathrm{H} 8$ protein was first purified by $\mathrm{Ni}$ affinity chromatography and then by gel filtration chromatography. Sodium dodecyl sulfate polyacrylamide gel electrophoresis (SDSPAGE) analysis showed that the purified $\mathrm{H} 8$ displayed an apparent molecular weight of approximately $33 \mathrm{kDa}$, accordant to that predicted from its sequence $(32.8 \mathrm{kDa})$ (Figure 3A). $\mathrm{H} 8$ could efficiently hydrolyze short-chain $p$ NP esters (C4-C10), with the maximal activity toward $p$ NPC6 $(69.0 \mathrm{U} / \mathrm{mg}$ ) (Figure 3B and Supplementary Figure 1). H8 showed a limited ability to degrade $p \mathrm{NP}$ esters longer than 10 carbon atoms, indicating that $\mathrm{H} 8$ is an esterase. $\mathrm{H} 8$ showed the highest activity at $35^{\circ} \mathrm{C}$ and retained $30 \%$ of its highest activity at $0^{\circ} \mathrm{C}$ (Figure 4A). $\mathrm{H} 8$ retained more than $80 \%$ of its highest activity after $1 \mathrm{~h}$ incubation at temperatures lower than $40^{\circ} \mathrm{C}$, but lost all the activity after $1 \mathrm{~h}$ incubation at $50^{\circ} \mathrm{C}$ (Figure 4B). $\mathrm{H} 8$ had the highest activity at $\mathrm{pH}$ 10.0 (Figure 5A) and showed good tolerance in a range of $\mathrm{pH} 6.0$ 9.0 , retaining over $80 \%$ of its highest activity after $1 \mathrm{~h}$ incubation in the buffers of $\mathrm{pH} 6.0-9.0$ at $25^{\circ} \mathrm{C}$ (Figure 5B).

The effect of metal ions on the activity of $\mathrm{H} 8$ was also investigated (Table 1). H8 activity was almost unaffected by
TABLE 1 | Effects of metal ions and potential inhibitors on H8 activity.

\begin{tabular}{|c|c|c|}
\hline \multirow[t]{2}{*}{ Compound } & \multicolumn{2}{|c|}{ Relative/Residual activity (\%) } \\
\hline & $1 \mathrm{mM}$ & $10 \mathrm{mM}$ \\
\hline $\mathrm{K}^{+}$ & $107.8 \pm 5.8$ & $107.6 \pm 1.5$ \\
\hline $\mathrm{Li}^{+}$ & $99.8 \pm 2.1$ & $86.1 \pm 3.1$ \\
\hline $\mathrm{Ba}^{2+}$ & $93.4 \pm 4.4$ & $59.4 \pm 2.8$ \\
\hline $\mathrm{Ca}^{2+}$ & $94.9 \pm 8.1$ & $90.9 \pm 6.1$ \\
\hline $\mathrm{Co}^{2+}$ & $84.9 \pm 0.8$ & $74.3 \pm 2.6$ \\
\hline $\mathrm{Cu}^{2+}$ & $82.2 \pm 2.7$ & $0.7 \pm 0.2$ \\
\hline $\mathrm{Fe}^{2+}$ & $85.0 \pm 1.4$ & $L D^{a}$ \\
\hline $\mathrm{Mg}^{2+}$ & $96.8 \pm 6.1$ & $84.1 \pm 5.4$ \\
\hline $\mathrm{Mn}^{2+}$ & $76.0 \pm 3.3$ & $57.2 \pm 2.6$ \\
\hline $\mathrm{Ni}^{2+}$ & $67.5 \pm 1.8$ & $57.1 \pm 1.7$ \\
\hline $\mathrm{Zn}^{2+}$ & $25.1 \pm 0.6$ & $11.5 \pm 0.4$ \\
\hline$\beta$-Mercaptoethanol & $78.6 \pm 3.1$ & $11.9 \pm 2.8$ \\
\hline DTT & $31.3 \pm 1.2$ & $5.0 \pm 2.7$ \\
\hline Thiourea & $111.5 \pm 1.2$ & $118.2 \pm 5.1$ \\
\hline Urea & $103.5 \pm 8.0$ & $115.2 \pm 4.0$ \\
\hline EDTA & $106.8 \pm 1.8$ & $114.4 \pm 1.3$ \\
\hline PMSF & $96.2 \pm 4.7$ & $33.4 \pm 1.1$ \\
\hline
\end{tabular}

a $L D$ indicates that the value was less than the limit of detection.

TABLE 2 | Effects of detergents on H8 activity.

\begin{tabular}{lccc}
\hline Detergent & \multicolumn{3}{c}{ Relative activity (\%) } \\
\cline { 2 - 4 } & $\mathbf{0 . 0 0 1 \% ( \mathbf { v } / \mathbf { v } )}$ & $\mathbf{0 . 0 1 \%}(\mathbf{v} / \mathbf{v})$ & $\mathbf{0 . 1 \%}(\mathbf{v} / \mathbf{v})$ \\
\hline Tween 20 & $128.9 \pm 5.6$ & $112.3 \pm 4.9$ & $110.6 \pm 3.4$ \\
Tween 80 & $102.9 \pm 3.4$ & $103.8 \pm 3.0$ & $112.3 \pm 2.7$ \\
Triton X-100 & $113.4 \pm 1.8$ & $84.2 \pm 0.5$ & $62.8 \pm 3.0$ \\
SDS & $33.0 \pm 0.6$ & $1.4 \pm 0.2$ & LD $^{\text {b }}$ \\
\hline
\end{tabular}

a The concentrations of SDS used were presented in $\mathrm{W} / \mathrm{V}$.

${ }^{\mathrm{b}} L D$ indicates that the value was less than the limit of detection.

TABLE 3 | Effects of organic solvents on H8 activity.

\begin{tabular}{lrr}
\hline Organic solvent & \multicolumn{2}{c}{ Relative activity (\%) } \\
\cline { 2 - 3 } & $\mathbf{1 0 \%}(\mathbf{v} / \mathbf{v})$ & $\mathbf{2 0 \%}(\mathbf{v} / \mathbf{v})$ \\
\hline Methanol & $122.5 \pm 4.6$ & $52.6 \pm 2.2$ \\
Ethanol & $120.4 \pm 8.6$ & $24.4 \pm 0.9$ \\
Isopropanol & $70.2 \pm 6.1$ & $4.4 \pm 0.3$ \\
Acetone & $82.3 \pm 3.0$ & $16.2 \pm 0.5$ \\
Acetonitrile & $65.6 \pm 3.5$ & $2.7 \pm 0.3$ \\
DMF & $109.9 \pm 3.5$ & $75.4 \pm 1.9$ \\
DMSO & $110.2 \pm 2.1$ & $104.7 \pm 1.9$ \\
\hline
\end{tabular}

$\mathrm{K}^{+}, \mathrm{Li}^{+}, \mathrm{Ca}^{2+}, \mathrm{Co}^{2+}$ or $\mathrm{Mg}^{2+}$ at $1 \sim 10 \mathrm{mM}$, but significantly inhibited by $\mathrm{Zn}^{2+}$ at $1 \sim 10 \mathrm{mM}$, and $\mathrm{Ba}^{2+}, \mathrm{Mn}^{2+}$, and $\mathrm{Ni}^{2+}$ at $10 \mathrm{mM}$, and fully inhibited by $\mathrm{Cu}^{2+}$ and $\mathrm{Fe}^{2+}$ at $10 \mathrm{mM}$. EDTA had no effect on H8 activity, suggesting that the catalysis by $\mathrm{H} 8$ may not require metal ions. $\mathrm{H} 8$ activity was significantly inhibited by $10 \mathrm{mM}$ PMSF, indicating that $\mathrm{H} 8$ is most likely a serine hydrolase. H8 activity was also severely inhibited by 

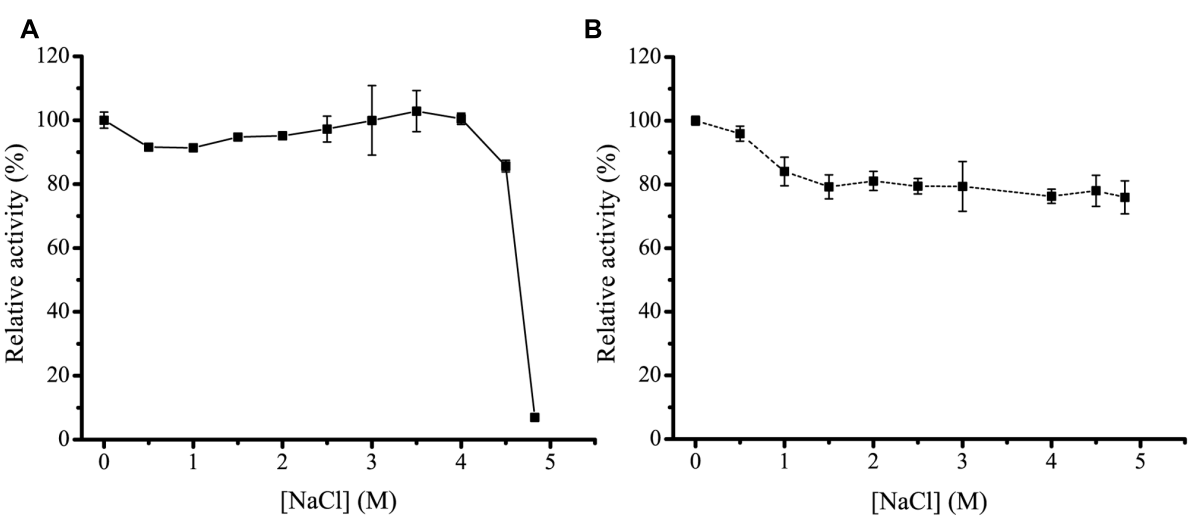

FIGURE 6 | Effect of $\mathrm{NaCl}$ on the activity and stability of $\mathbf{H 8}$. (A) Effect of $\mathrm{NaCl}$ on the activity of $\mathrm{H} 8$. The activity was measured at $35^{\circ} \mathrm{C}$ in 50 mM Tris- $\mathrm{HCl}$ buffer with different concentrations of $\mathrm{NaCl}$. The activity in $0 \mathrm{M} \mathrm{NaCl}(70.9 \mathrm{U} / \mathrm{mg})$ was taken as $100 \%$. (B) Effect of $\mathrm{NaCl}$ on the stability of $\mathrm{H} 8$. The enzyme was incubated at $0^{\circ} \mathrm{C}$ for $1 \mathrm{~h}$ in buffers containing $\mathrm{NaCl}$ ranging from 0 to $4.6 \mathrm{M}$. The remaining activity was measured under optimal conditions. The activity in $0 \mathrm{M} \mathrm{NaCl}$ (68.6 U/mg) was taken as 100\%. The graphs show data from triplicate experiments (mean $\pm \mathrm{SD}$ ).

TABLE 4 | Comparison of the amino acid composition of $\mathrm{H8}$ and its homologs and reported halotolerant enzymes.

\begin{tabular}{|c|c|c|c|c|c|}
\hline & Halotolerant H8 & H8 homologs & Halophilic VsEndA & Halotolerant PE10 & Halophilic Hm EST \\
\hline pl value & 9.09 & $7.96-10.28$ & 9.57 & 4.65 & 4.24 \\
\hline Arg + Lys (\%) & 10.49 & $10.00-11.84$ & 17.06 & 6.45 & 5.8 \\
\hline Asp + Glu (\%) & 9.18 & 8.20-9.97 & 9.48 & 10.75 & 16.8 \\
\hline$(\operatorname{Arg}+$ Lys)/(Asp + Glu $)$ & 1.14 & $1.03-1.38$ & 1.80 & 0.60 & 0.35 \\
\hline Sequence identity to $\mathrm{H}^{\mathrm{a}}$ & $100 \%$ & $44-99 \%$ & - & - & - \\
\hline
\end{tabular}

a -, no sequence identity detected.

reductants DTT and $\beta$-mercaptoethanol. However, H8 showed high resistance to chaotropic agents urea and thiourea (Table 1). $\mathrm{H} 8$ activity was slightly increased by $0.001-0.1 \%(\mathrm{v} / \mathrm{v})$ Tween 20 , but fully inhibited by $0.01 \%(\mathrm{w} / \mathrm{v})$ SDS (Table 2). Among all the tested organic solvents at $10 \%(\mathrm{v} / \mathrm{v})$ concentration, methanol, ethanol, DMF, and DMSO slightly increased H8 activity, and other detergents slightly reduced $\mathrm{H} 8$ activity. At 20\% (v/v) concentration, DMF and DMSO had nearly no effect on H8 activity, whereas other detergents significantly inhibited H8 activity (Table 3).

\section{High Salt Tolerance of $\mathbf{H 8}$}

Because the $\mathrm{H} 8$ gene is isolated from a deep-sea sediment, we investigated the effect of $\mathrm{NaCl}$ of different concentrations on the activity and stability of $\mathrm{H} 8 \mathrm{H} 8$ still had full activity in $\mathrm{NaCl}$ with a concentration as high as $4.0 \mathrm{M}$ (Figure 6A), indicating that $\mathrm{H} 8$ has high salt tolerance. Moreover, after $1 \mathrm{~h}$ incubation in $4.6 \mathrm{M}$ $\mathrm{NaCl}, \mathrm{H} 8$ still retained $80 \%$ activity (Figure 6B). These results show that $\mathrm{H} 8$ is a halotolerant enzyme.

\section{High Contents of Basic Residues in H8}

Unlike most reported halophilic/halotolerant enzymes that have high acidic/basic residue ratios and relatively low pI values ranging from 4.3 to 6.8 ( $\mathrm{Ng}$ et al., 2000; Kennedy et al., 2001; Dassarma et al., 2013), H8 contains more basic residues (10.49\%) than acidic residues (9.18\%) (Table 4), leading to a high predicted pI value of 9.09. By searching NCBI nr database using the H8 sequence as a query, more than 10 homologs of $\mathrm{H} 8$ are found to have more basic residues than acidic residues and high $\mathrm{pI}$ values (Table 4), suggesting that $\mathrm{H} 8$ and its homologs may represent an uncharacterized group of lipolytic enzymes rich in basic residues.

\section{The Role of Basic Residues in the Salt Tolerance of $\mathbf{H 8}$}

Until now, only one halophilic enzyme, the endonuclease $V s$ EndA from $V$. salmonicida, is found to have an overwhelming number of basic residues distributed on the protein surface for its haloadaption (Altermark et al., 2008). To study the roles of the basic residues, especially the surface basic residues, in the salt tolerance of $\mathrm{H} 8$, we tried to obtain its crystal structure or modeled structure. Unfortunately, the crystal structure of $\mathrm{H} 8$ was unable to be solved due to the low resolution of the H8 crystals we obtained. In addition, due to the low sequence identity (lower than 28\%) between $\mathrm{H} 8$ and reported proteins with resolved structures, no modeled structure of $\mathrm{H} 8$ could be constructed. Finally, according to multiple sequence alignment (Figure 2), we selected five basic residues (Arg195, Arg203, Arg216, Arg236, and Arg263) for site-directed mutation to acidic Glu to investigate their roles in H8 halotolerance. Residues Arg195 and Arg263 are partially conserved and residues Arg203, Arg216, and Arg236 are highly conserved in $\mathrm{H} 8$ homologs (Figure 2).

The effect of $\mathrm{NaCl}$ on the activities and stabilities of the mutants was measured and compared to WT H8 (Figure 7). Under their respective optimum temperatures, the effect of $\mathrm{NaCl}$ 

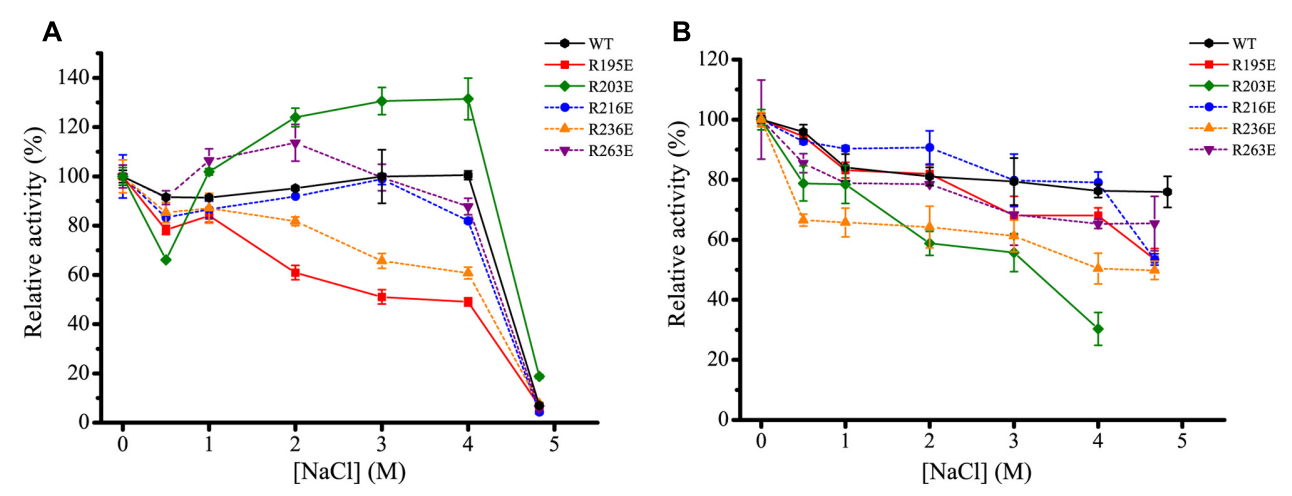

FIGURE 7 | Effect of $\mathbf{N a C l}$ on the activity and stability of the mutants of $\mathbf{H 8}$. (A) Effect of $\mathrm{NaCl}$ on the activity of WT $\mathrm{H} 8$ and its mutants. The activities of $\mathrm{H} 8$ and its mutants were determined at different $\mathrm{NaCl}$ concentrations at their respective optimum temperatures. The activities of WT $\mathrm{H} 8$ (70.9 U/mg), R195E (65.6 U/mg), R203E (7.5 U/mg), R216E (82.6 U/mg), R236E (53.0 U/mg), and R263E (62.0 U/mg) in $0 \mathrm{M} \mathrm{NaCl}$ were taken as $100 \%$, respectively. (B) Effect of NaCl on the stability of WT $\mathrm{H} 8$ and its mutants. The enzymes were incubated in buffers containing different $\mathrm{NaCl}$ concentrations at $\mathrm{O}^{\circ} \mathrm{C}$ for $1 \mathrm{~h}$, and the residual activity was measured at their optimum temperatures, respectively. The activities of WT H8 (68.6 U/mg), R195E (64.5 U/mg), R203E (6.7 U/mg), R216E (72.8 U/mg), R236E $(48.8 \mathrm{U} / \mathrm{mg})$, and R263E (61.0 U/mg) in $0 \mathrm{M} \mathrm{NaCl}$ were taken as $100 \%$, respectively. The graphs show data from triplicate experiments (mean \pm SD).
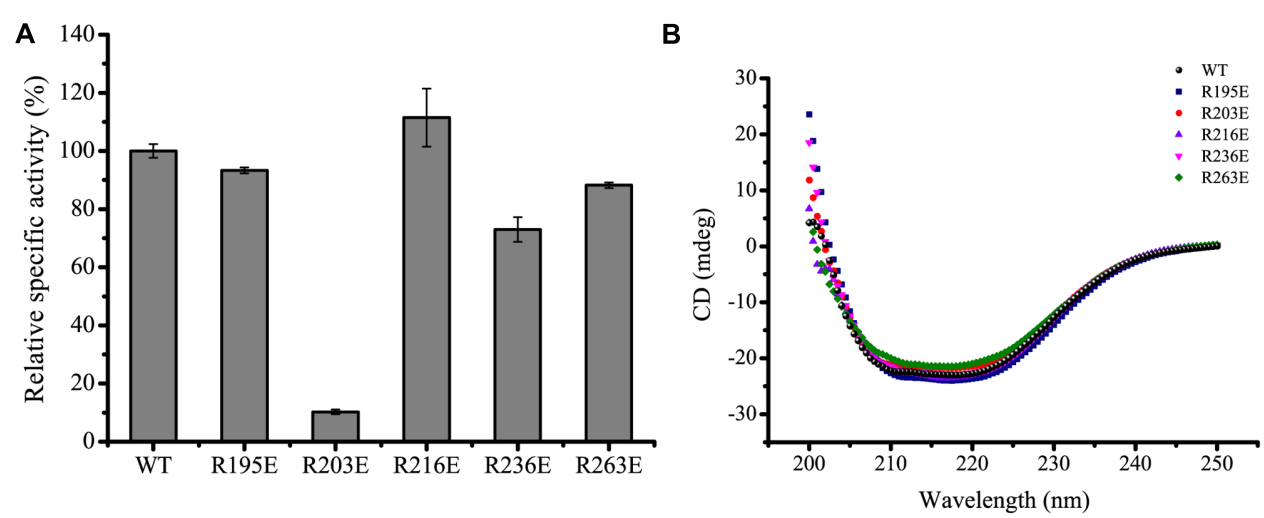

FIGURE 8 | Relative specific activities and circular dichroism (CD) spectra of WT H8 and its mutants. (A) Relative specific activities of WT H8 and its mutants. The specific activity of WT H8 $(69.7 \mathrm{U} / \mathrm{mg})$ was defined as $100 \%$. (B) CD spectra of WT H8 and its mutants. All the spectra were collected from 200 to $250 \mathrm{~nm}$ at a scanning speed of $200 \mathrm{~nm} / \mathrm{min}$ with a path length of $0.1 \mathrm{~cm}$. The graphs show data from triplicate experiments (mean \pm SD).

TABLE 5 | Impact of mutations on $\mathrm{H} 8$ stability and activity.

\begin{tabular}{|c|c|c|c|c|c|}
\hline Enzyme & $T_{\text {opt }}\left({ }^{\circ} \mathrm{C}\right)$ & $V_{\max }(\mu \mathrm{M} / \mathrm{min} / \mathrm{mg})$ & $K_{\mathrm{m}}(\mathrm{mM})$ & $k_{\text {cat }}\left(s^{-1}\right)$ & $k_{\text {cat }} / K_{\mathrm{m}}\left(\mathrm{mM}^{-1} \mathrm{~s}^{-1}\right)$ \\
\hline WT & 35 & $73.36 \pm 1.91$ & $0.074 \pm 0.014$ & $40.10 \pm 1.04$ & 539.8 (100\%) \\
\hline R195E & 30 & $51.96 \pm 2.92$ & $0.052 \pm 0.011$ & $28.41 \pm 1.59$ & 546.2 (101.2\%) \\
\hline R203E & 30 & $8.50 \pm 1.09$ & $0.070 \pm 0.002$ & $4.64 \pm 0.59$ & $66.6(12.3 \%)$ \\
\hline R216E & 35 & $74.49 \pm 2.63$ & $0.072 \pm 0.008$ & $40.72 \pm 2.44$ & 546.7 (101.3\%) \\
\hline R236E & 30 & $46.53 \pm 1.54$ & $0.053 \pm 0.003$ & $25.44 \pm 0.84$ & $481.8(89.3 \%)$ \\
\hline R263E & 35 & $50.01 \pm 2.37$ & $0.058 \pm 0.008$ & $26.64 \pm 1.19$ & $459.3(85.1 \%)$ \\
\hline
\end{tabular}

on the activities and stabilities of mutants R216E and R263E was similar to that of the WT (Figures 7A,B), suggesting that these two residues $\operatorname{Arg} 216$ and Arg263 may not be related to the salt tolerance of H8. In addition, mutants R216E and R263E had similar $K_{\mathrm{m}}$ and $k_{\text {cat }}$ values and specific activities to the WT (Figure 8A and Table 5), indicating that these two mutations had little effect on the substrate binding and catalysis of $\mathrm{H} 8$ and that Arg216 and Arg263 are potentially surface residues.
Although the activity of mutant R203E was slightly stimulated by 1.2 - to 1.3 -fold in $\mathrm{NaCl}$ ranging from 2.0 to $4.0 \mathrm{M}$, its stability was significantly reduced in increased concentrations of $\mathrm{NaCl}$. After incubated in $4.0 \mathrm{M} \mathrm{NaCl}$ for $1 \mathrm{~h}, \mathrm{H} 8$ retained $80 \%$ activity, whereas R203E retained only $30 \%$ activity, indicating that mutant R203E is less tolerant than the WT under high salts. Mutation R203E had no impact on the $K_{\mathrm{m}}$ of $\mathrm{H} 8$, but significantly reduced its $k_{\text {cat }}$ and specific activity (Figure 8A and Table 5). These data 
suggest that Arg203 might be directly or indirectly involved in the catalysis of $\mathrm{H} 8$.

The effect of $\mathrm{NaCl}$ on the stability of mutant R195E was similar to that of the WT, whereas its activity was significantly reduced by $\mathrm{NaCl}$. Compared to WT H8, the activity of mutant R195E in $4 \mathrm{M} \mathrm{NaCl}$ was reduced by $51 \%$, suggesting its potential role in the salt tolerance of H8. Mutation R195E had no impact on the specific activity of $\mathrm{H} 8$ and small impact on the $K_{\mathrm{m}}$ and $k_{\text {cat }}$ values (Figure 8A and Table 5), indicating that Arg195 is potentially located on the surface of $\mathrm{H} 8$ protein.

For mutant R236E, both the activity and stability was significantly reduced in increased concentrations of $\mathrm{NaCl}$, suggesting that Arg236 may play an important role in the salt tolerance of H8. Mutant R236E had only small effect on the substrate binding and catalysis of $\mathrm{H} 8$ (Table 5), suggesting that residue Arg236 is potentially a surface residue.

Circular dichroism spectral analysis showed that these mutations caused no visible changes in H8 structure (Figure 8B), indicating that the decrease in the enzymatic activity and stability of the mutants resulted from residue substitution rather than structural changes.

\section{DISCUSSION}

In this study, a metagenomic library containing 7,200 fosmid clones was constructed from a deep-sea sediment sample from the South China Sea to functionally screen lipolytic enzymeencoding genes, and a gene encoding an esterase $\mathrm{H} 8$ was identified, cloned and over-expressed. Phylogenetic analysis showed that $\mathrm{H} 8$ belongs to the family $\mathrm{V}$ of bacterial lipolytic enzymes. Among the characterized lipolytic enzymes, H8 has the highest identity (46\%) to Est16 from a microbial consortium specialized for diesel oil degradation (Pereira et al., 2015). However, H8 shows different substrate specificities from Est16 (Pereira et al., 2015). H8 can efficiently hydrolyze short-chain monoesters (C4-C10), especially for $p$ NPC6 and $p$ NPC8, while Est16 prefers to hydrolyze pNPC4 and pNPC5 (Pereira et al., 2015). Therefore, $\mathrm{H} 8$ is a new family $\mathrm{V}$ esterase.

A few halotolerant/halophilic lipolytic enzymes have been reported. Consistent with other known halotolerant/halophilic enzymes, halotolerant/halophilic lipolytic enzymes contain more acidic residues (Asp and Glu) than basic residues in their sequences, leading to their low pI values ( $\mathrm{Ng}$ et al., 2000; Kennedy et al., 2001; Dassarma et al., 2013). Moreover, modeled structural analysis suggests that a large number of negatively charged acidic residues are distributed over the protein surface of halotolerant/halophilic lipolytic enzymes, which may form a protective solvation shell to keep the protein surface hydrated and promote the adaption of the protein to salinity (De Santi et al., 2016; Wang et al., 2016). Until now, reports on the salt tolerance of family $\mathrm{V}$ lipolytic enzymes are still scarce. We studied the effect of $\mathrm{NaCl}$ on the activity and stability of H8. The result showed that $\mathrm{H} 8$ has high halotolerance. However, unlike most reported halotolerant/halophilic enzymes, $\mathrm{H} 8$ contains a large number of basic residues in sequence, leading to its high basic/acidic residue ratio and high $\mathrm{pI}$ value (9.09). In addition, more than 10 homologous sequences with similar basic/acidic residue ratios and predicted $\mathrm{pI}$ values to $\mathrm{H} 8$ are found in NCBI nr database. Therefore, $\mathrm{H} 8$ and its homologs may represent a new subgroup of family $\mathrm{V}$ halotolerant lipolytic enzymes rich in basic residues.

Up to date, only a halophilic endonuclease $V$ sEndA from $V$. salmonicida is reported to contain more basic residues than acidic residues and have high pI value (9.57) (Altermark et al., 2008). Moreover, structural analysis shows that the protein surface of $V$ sEndA is populated with positively charged basic residues, which may result in the haloadaption of $V$ sEndA (Altermark et al., 2008). We studied the roles of five conserved basic residues in the salt tolerance of $\mathrm{H} 8$ by residue replacement. The results suggested that Arg195, Arg203, and Arg236 may play a role in the salt tolerance of H8, but Arg216 and Arg263 have little effect on the salt tolerance of H8. However, due to the lack of $\mathrm{H} 8$ structure, it is difficult to determine the exact positions and roles of these basic residues in $\mathrm{H} 8$, which still need further study.

In addition, H8 is also a cold-adapted enzyme. H8 had a low optimal temperature $\left(35^{\circ} \mathrm{C}\right)$ for activity and still remained $30 \%$ of the maximal activity at $0^{\circ} \mathrm{C}$. The halotolerant and coldadapted characteristics indicate that $\mathrm{H} 8$ is well adapted to deepsea sediment and may play a role in marine organic degradation and carbon cycling. Moreover, the good halotolerance of H8 implies its potentials in harsh industrial processes requiring high salts, low water activity, and the presence of organic solvents (such as DMSO).

\section{AUTHOR CONTRIBUTIONS}

$\mathrm{YZ}, \mathrm{JH}$, and Y-QZ performed all experiments. P-YL and X-LC directed the experiments. YZ and P-YL wrote the manuscript. B-BX and MS helped in data analysis. Y-ZZ and B-CZ designed the research.

\section{ACKNOWLEDGMENTS}

This work was supported by the National Science Foundation of China (grants 31290231, 91328208, 31670497, and 41676180), and the Program of Shandong for Taishan Scholars (TS200 90803).

\section{SUPPLEMENTARY MATERIAL}

The Supplementary Material for this article can be found online at: http://journal.frontiersin.org/article/10.3389/fmicb. 2017.00441/full\#supplementary-material 


\section{REFERENCES}

Altermark, B., Helland, R., Moe, E., Willassen, N. P., and Smalas, A. O. (2008). Structural adaptation of endonuclease I from the cold-adapted and halophilic bacterium Vibrio salmonicida. Acta Crystallogr. D Biol. Crystallogr. 64(Pt 4), 368-376. doi: 10.1107/S0907444908000097

Arpigny, J. L., and Jaeger, K. E. (1999). Bacterial lipolytic enzymes: classification and properties. Biochem. J. 343(Pt 1), 177-183. doi: 10.1042/bj343 0177

Chen, K., Liu, Y., Mao, D. M., Liu, X. M., Li, S. P., and Jiang, J. D. (2013). An essential esterase (BroH) for the mineralization of bromoxynil octanoate by a natural consortium of Sphingopyxis sp. strain OB-3 and Comamonas sp. strain 7D-2. J. Agric. Food Chem. 61, 11550-11559. doi: 10.1021/jf40 37062

Chu, X., He, H., Guo, C., and Sun, B. (2008). Identification of two novel esterases from a marine metagenomic library derived from South China Sea. Appl. Microbiol. Biotechnol. 80, 615-625. doi: 10.1007/s00253-008-1566-3

Dassarma, S., Capes, M. D., Karan, R., and Dassarma, P. (2013). Amino acid substitutions in cold-adapted proteins from Halorubrum lacusprofundi, an extremely halophilic microbe from antarctica. PLOS ONE 8:e58587. doi: 10. 1371/journal.pone.0058587

De Santi, C., Leiros, H. K., Di Scala, A., de Pascale, D., Altermark, B., and Willassen, N. P. (2016). Biochemical characterization and structural analysis of a new coldactive and salt-tolerant esterase from the marine bacterium Thalassospira sp. Extremophiles 20, 323-336. doi: 10.1007/s00792-016-0824-z

Edgar, R. C. (2004). MUSCLE: multiple sequence alignment with high accuracy and high throughput. Nucleic Acids Res. 32, 1792-1797. doi: 10.1093/nar/ gkh340

Elcock, A. H., and Mccammon, J. A. (1998). Electrostatic contributions to the stability of halophilic proteins 1. J. Mol. Biol. 280, 731-748. doi: 10.1006/jmbi. 1998.1904

Fang, Z., Li, J., Wang, Q., Fang, W., Peng, H., Zhang, X., et al. (2014). A novel esterase from a marine metagenomic library exhibiting salt tolerance ability. J. Microbiol. Biotechnol. 24, 771-780. doi: 10.4014/jmb.1311. 11071

Handelsman, J. (2004). Metagenomics: application of genomics to uncultured microorganisms. Microbiol. Mol. Biol. Rev. 68, 669-685. doi: 10.1128/MMBR. 68.4.669-685.2004

Jaeger, K. E., Dijkstra, B. W., and Reetz, M. T. (1999). Bacterial biocatalysts: molecular biology, three-dimensional structures, and biotechnological applications of lipases. Annu. Rev. Microbiol. 53, 315-351. doi: 10.1146/ annurev.micro.53.1.315

Jeon, J. H., Lee, H. S., Kim, J. T., Kim, S. J., Choi, S. H., Kang, S. G., et al. (2012). Identification of a new subfamily of salt-tolerant esterases from a metagenomic library of tidal flat sediment. Appl. Microbiol. Biotechnol. 93, 623-631. doi: 10.1007/s00253-011-3433-x

Kennedy, S. P., Ng, W. V., Salzberg, S. L., Hood, L., and DasSarma, S. (2001). Understanding the adaptation of Halobacterium species NRC-1 to its extreme environment through computational analysis of its genome sequence. Genome Res. 11, 1641-1650. doi: 10.1101/gr.190201

Kim, E. Y., Oh, K. H., Lee, M. H., Kang, C. H., Oh, T. K., and Yoon, J. H. (2009). Novel cold-adapted alkaline lipase from an intertidal flat metagenome and proposal for a new family of bacterial lipases. Appl. Environ. Microbiol. 75, 257-260. doi: 10.1128/AEM.01400-08

Li, P. Y., Ji, P., Li, C. Y., Zhang, Y., Wang, G. L., Zhang, X. Y., et al. (2014). Structural basis for dimerization and catalysis of a novel esterase from the GTSAG motif subfamily of the bacterial hormone-sensitive lipase family. J. Biol. Chem. 289, 19031-19041. doi: 10.1074/jbc.M114.574913

Liu, H., and Naismith, J. H. (2008). An efficient one-step site-directed deletion, insertion, single and multiple-site plasmid mutagenesis protocol. BMC Biotechnol. 8:91. doi: 10.1186/1472-6750-8-91

Ng, W. V., Kennedy, S. P., Mahairas, G. G., Berquist, B., Pan, M., Shukla, H. D., et al. (2000). Genome sequence of Halobacterium species NRC1. Proc. Natl. Acad. Sci. U.S.A. 97, 12176-12181. doi: 10.1073/pnas.19033 7797

Oren, A., Larimer, F., Richardson, P., Lapidus, A., and Csonka, L. N. (2005). How to be moderately halophilic with broad salt tolerance: clues from the genome of Chromohalobacter salexigens. Extremophiles 9, 275-279. doi: 10.1007/s00792005-0442-7
Peng, Q., Zhang, X., Shang, M., Wang, X., Wang, G., Li, B., et al. (2011). A novel esterase gene cloned from a metagenomic library from neritic sediments of the South China Sea. Microb. Cell Fact. 10:95. doi: 10.1186/1475-2859-10-95

Pereira, M. R., Mercaldi, G. F., Maester, T. C., Balan, A., and Lemos, E. G. (2015). Est16, a new esterase isolated from a metagenomic library of a microbial consortium specializing in diesel oil degradation. PLoS ONE 10:e0133723. doi: 10.1371/journal.pone.0133723

Perez, D., Martin, S., Fernandez-Lorente, G., Filice, M., Guisan, J. M., Ventosa, A., et al. (2011). A novel halophilic lipase, LipBL, showing high efficiency in the production of eicosapentaenoic acid (EPA). PLoS ONE 6:e23325. doi: 10.1371/ journal.pone.0023325

Petersen, T. N., Brunak, S., von Heijne, G., and Nielsen, H. (2011). SignalP 4.0: discriminating signal peptides from transmembrane regions. Nat. Methods 8, 785-786. doi: $10.1038 /$ nmeth.1701

Placido, A., Hai, T., Ferrer, M., Chernikova, T. N., Distaso, M., Armstrong, D., et al. (2015). Diversity of hydrolases from hydrothermal vent sediments of the Levante Bay, Vulcano Island (Aeolian archipelago) identified by activitybased metagenomics and biochemical characterization of new esterases and an arabinopyranosidase. Appl. Microbiol. Biotechnol. 99, 10031-10046. doi: 10. 1007/s00253-015-6873-x

Prive, F., Kaderbhai, N. N., Girdwood, S., Worgan, H. J., Pinloche, E., Scollan, N. D., et al. (2013). Identification and characterization of three novel lipases belonging to families II and V from Anaerovibrio lipolyticus 5ST. PLoS ONE 8:e69076. doi: 10.1371/journal.pone.0069076

Rao, L., Zhao, X., Pan, F., Li, Y., Xue, Y., Ma, Y., et al. (2009). Solution behavior and activity of a halophilic esterase under high salt concentration. PLoS ONE 4:e6980. doi: 10.1371/journal.pone.0006980

Schloss, P. D., and Handelsman, J. (2003). Biotechnological prospects from metagenomics. Curr. Opin. Biotechnol. 14, 303-310. doi: 10.1016/S09581669(03)00067-3

Shirai, K., and Jackson, R. L. (1982). Lipoprotein lipase-catalyzed hydrolysis of p-nitrophenyl butyrate. Interfacial activation by phospholipid vesicles. J. Biol. Chem. 257, 1253-1258.

Sumby, K. M., Grbin, P. R., and Jiranek, V. (2013). Characterization of EstCOo8 and EstC34, intracellular esterases, from the wine-associated lactic acid bacteria Oenococcus oeni and Lactobacillus hilgardii. J. Appl. Microbiol. 114, 413-422. doi: 10.1111/jam.12060

Tamura, K., Stecher, G., Peterson, D., Filipski, A., and Kumar, S. (2013). MEGA6: molecular evolutionary genetics analysis version 6.0. Mol. Biol. Evol. 30, 2725-2729. doi: 10.1093/molbev/mst197

Tchigvintsev, A., Tran, H., Popovic, A., Kovacic, F., Brown, G., Flick, R., et al. (2015). The environment shapes microbial enzymes: five cold-active and salt-resistant carboxylesterases from marine metagenomes. Appl. Microbiol. Biotechnol. 99, 2165-2178. doi: 10.1007/s00253-014-6038-3

Ventosa, A., Fernández, A. B., León, M. J., Sánchez-Porro, C., and RodriguezValera, F. (2014). The Santa Pola saltern as a model for studying the microbiota of hypersaline environments. Extremophiles 18, 811-824. doi: 10.1007/s00792014-0681-6

Wang, G., Wang, Q., Lin, X., Ng, T. B., Yan, R., Lin, J., et al. (2016). A novel coldadapted and highly salt-tolerant esterase from Alkalibacterium sp. SL3 from the sediment of a soda lake. Sci. Rep. 6:19494. doi: 10.1038/srep19494

Wu, G., Wu, G., Zhan, T., Shao, Z., and Liu, Z. (2013). Characterization of a cold-adapted and salt-tolerant esterase from a psychrotrophic bacterium Psychrobacter pacificensis. Extremophiles 17, 809-819. doi: 10.1007/s00792-0130562-4

Zhou, J., Bruns, M. A., and Tiedje, J. M. (1996). DNA recovery from soils of diverse composition. Appl. Environ. Microbiol. 62, 316-322.

Conflict of Interest Statement: The authors declare that the research was conducted in the absence of any commercial or financial relationships that could be construed as a potential conflict of interest.

Copyright (c) 2017 Zhang, Hao, Zhang, Chen, Xie, Shi, Zhou, Zhang and Li. This is an open-access article distributed under the terms of the Creative Commons Attribution License (CC BY). The use, distribution or reproduction in other forums is permitted, provided the original author(s) or licensor are credited and that the original publication in this journal is cited, in accordance with accepted academic practice. No use, distribution or reproduction is permitted which does not comply with these terms. 